\title{
Ammoxidation of propane to acrylonitrile over silica-supported Fe-Bi nanocatalysts
}

\author{
Richard D. Adams ${ }^{\ddagger *}$, Gaya Elpitiya ${ }^{\ddagger}$, Konstantin Khivantsev ${ }^{\S}$, Douglas Blom ${ }^{\S \S}$, \\ Oleg S. Alexeev $\S^{{ }^{*}}$, and Michael D. Amiridis ${ }^{{ }^{*}}$. \\ ${ }^{\ddagger}$ Department of Chemistry and Biochemistry \\ University of South Carolina \\ Columbia, SC 29208, USA \\ ${ }^{\S}$ Department of Chemical Engineering \\ University of South Carolina \\ Columbia, SC 29208, USA \\ ${ }^{\S}$ Electron Microscopy Center \\ University of South Carolina \\ Columbia, SC 29208, USA
}

*Corresponding authors. E-mail addresses: alexeev@cec.sc.edu (O.S. Alexeev),

amiridis@uic.edu (M.D. Amiridis), adamsrd@mailbox.sc.edu (R.D. Adams) 


\begin{abstract}
Ammoxidation of propane to acrylonitrile was examined over a $\mathrm{Fe}_{3} \mathrm{BiO}_{\mathrm{x}} / \mathrm{SiO}_{2}$ sample prepared by thermal decarbonylation of $\left[\mathrm{Et}_{4} \mathrm{~N}\right]\left[\mathrm{Fe}_{3}(\mathrm{CO})_{10}\left(\mu_{3}-\mathrm{Bi}\right)\right]$ on the surface of mesoporous silica. Catalytic measurements performed at $500^{\circ} \mathrm{C}$ showed that this sample yields $49 \%$ acrylonitrile selectivity at $36 \%$ propane conversion when a $5.5 \% \mathrm{C}_{3} \mathrm{H}_{8} / 30 \% \mathrm{O}_{2} / 11 \% \mathrm{NH}_{3} / \mathrm{He}$ balance reaction mixture was used at a GHSV of $1360 \mathrm{~h}^{-1}$. HRSTEM, EDS, and XPS measurements indicate that mixed $\mathrm{Fe}_{3} \mathrm{BiO}_{6}$ oxide particles less than $2 \mathrm{~nm}$ in size were formed on the surface of this material under reaction conditions. A Fe/ $\mathrm{Bi}$ atomic ratio in these particles is approximately $3: 1$ and the $\mathrm{Fe}$ and $\mathrm{Bi}$ ions both are in the +3 oxidation state. $\mathrm{A} \mathrm{Fe}-\mathrm{Bi} / \mathrm{SiO}_{2}$ sample prepared by co-impregnation of individual Fe and Bi salts had very low activity and low selectivity for acrylonitrile formation from propane under similar experimental conditions due to larger sizes of particles formed under reaction conditions and enrichment of their surface with Fe.
\end{abstract}

Keywords: Propane ammoxidation; Mixed FeBi oxides; Nanoparticles; Cluster-derived catalyst; XPS; HRSTEM; EDS. 


\section{Introduction}

The ammoxidation of propene to acrylonitrile (Eq. (1)) catalyzed by bismuth molybdates is one of world's largest commercial processes for the production of a commodity chemical [1-3].

$$
\mathrm{C}_{3} \mathrm{H}_{6}+3 / 2 \mathrm{O}_{2}+\mathrm{NH}_{3} \rightarrow \mathrm{CH}_{2} \mathrm{CHCN}+3 \mathrm{H}_{2} \mathrm{O}
$$

Experimental and computational results have indicated that the critical alkene activation step occurs at the methyl group of propene by a Bi-O function in the bismuth-molybdate catalysts [49]. Supported catalysts incorporating bismuth have also been shown to catalyze the oxidation of different aromatic and alkane compounds [10-12]. There is considerable interest in developing selective oxidation and ammoxidation reactions by using less expensive and widely available saturated hydrocarbons and considerable efforts have been made to utilize propane as a feedstock for the synthesis of acrylonitrile [13-33].

Literature reports have shown that iron-antimony oxide catalysts exhibit significant activity for the oxidation and ammoxidation of propane [34] and propene [35]. Catlow et al. [36] have examined possible mechanisms of propane ammoxidation over $\mathrm{FeSbO}_{4}$ catalysts by computational methods and identified two possible pathways: one that starts with hydrogen abstraction from the methylene group in propane and proceeds through a propylene intermediate and a second one that starts with hydrogen abstraction from one of the methyl groups. These two mechanisms have similar energy barriers, resulting in similar temperatures at which the products are formed. Moreover, the antimony and oxygen atoms were found to play key roles in the $\mathrm{CH}$ activation steps of the hydrocarbon.

While antimony and bismuth have similar chemical properties, there are virtually no literature examples of propane ammoxidation over iron-bismuth catalytic materials. A number of years ago, it was reported that ternary iron-bismuth-phosphorus oxide systems are effective catalysts for the ammoxidation of propene [37] and acrolein [38]. More recently, it has been shown that catalytic properties of supported bimetallic catalysts incorporating bismuth can be significantly improved by using bismuth-transition metal carbonyl cluster complexes as precursors $[39,40]$. Accordingly, we have now examined the ability of $\mathrm{SiO}_{2}$-supported ironbismuth nanoparticles prepared from iron-bismuth carbonyl cluster complexes to catalyze the reaction of propane ammoxidation to form acrylonitrile. These results are reported herein. 


\section{Experimental}

Reagent grade solvents were dried by the standard procedures and freshly distilled under nitrogen prior to use. [Et $\left.{ }_{4} \mathrm{~N}\right]\left[\mathrm{Fe}_{3}(\mathrm{CO})_{10}\left(\mu_{3}-\mathrm{Bi}\right)\right], \mathbf{1}$ was prepared as reported elsewhere [41]. The $\mathrm{Fe}(\mathrm{CO})_{5}$ (STREM) and $\mathrm{NaBiO}_{3}$ (Sigma-Aldrich) compounds were used in the preparation routine without further purification.

\subsection{Catalyst Preparation}

The cluster-derived catalyst (further denoted as $\mathrm{Fe}_{3} \mathrm{BiO} \times / \mathrm{SiO}_{2}$ ) was prepared from the bimetallic precursor 1: $520 \mathrm{mg}$ of 1 was dissolved in $100 \mathrm{~mL}$ of $\mathrm{CH}_{2} \mathrm{Cl}_{2} .5 .00 \mathrm{~g}$ of Davisil 923 (pore size $30 \AA, 100-200$ mesh, Grace Davison) mesoporous silica support was added to this solution and the slurry was stirred under nitrogen for $24 \mathrm{~h}$. The solvent was then slowly removed under vacuum. Finally, the impregnated sample was heated under vacuum to $200^{\circ} \mathrm{C}$ for a period of approximately $2 \mathrm{~h}$ to remove the CO ligands, yielding $5.25 \mathrm{~g}$ of supported catalyst with $5 \%$ metal loading.

For comparison, the $\mathrm{Fe}-\mathrm{Bi} / \mathrm{SiO}_{2}$ sample with a $\mathrm{Fe} / \mathrm{Bi}$ molar ratio of 3 was prepared by coimpregnation: $85.9 \mathrm{mg}$ of $\mathrm{FeBr}_{2}$ and $41.9 \mathrm{mg}$ of $\mathrm{BiCl}_{3}$ were dissolved in $100 \mathrm{~mL}$ of acetonitrile (NCMe). Following the addition of $1.00 \mathrm{~g}$ of Davisil 923 mesoporous silica support, the mixture was stirred under nitrogen for $24 \mathrm{~h}$. After the solvent was slowly removed by evacuation, the resulting material was heated under vacuum to $200^{\circ} \mathrm{C}$ for a period of approximately $2 \mathrm{~h}$ to yield $1.05 \mathrm{~g}$ of catalyst with $5 \%$ metal loading.

\subsection{Characterizations}

\subsubsection{High Resolution Scanning Transmission Electron Microscopy}

High resolution scanning transmission electron microscopy (HRSTEM) was performed at the University of South Carolina Electron Microscopy Center using a JEOL 2100F 200kV FEG$\mathrm{STEM} / \mathrm{TEM}$ equipped with a CEOS $\mathrm{C}_{\mathrm{s}}$ corrector on the illumination system. The geometrical aberrations were measured and controlled to provide less than a $\pi / 4$ phase shift of the incoming electron wave over the probe-defining aperture of $17.5 \mathrm{mrad}$. High angle annular dark-field (HAADF) high resolution scanning transmission electron microscopy (HRSTEM) images were 
acquired on a Fischione Model 3000 HAADF detector with a camera length such that the inner cut-off angle of the detector was $50 \mathrm{mrad}$. The scanning acquisition was synchronized to the 60 $\mathrm{Hz} \mathrm{AC}$ electrical power to minimize $60 \mathrm{~Hz}$ noise in the images and a pixel dwell time of $15.8 \mu \mathrm{s}$ was used. Particle size distributions were obtained by observing and including at least 300 particles from several different images. The surface-averaged size of particles was calculated as $\frac{\sum_{i} n_{i} d_{i}^{3}}{\sum_{i} n_{i} d_{i}^{2}} \quad$ (where $\mathrm{n}_{\mathrm{i}}$ is the number of particles with the $\mathrm{d}_{\mathrm{i}}$ diameter).

\subsubsection{X-ray Photoelectron Spectroscopy (XPS)}

A Kratos AXIS Ultra DLD X-ray photoelectron spectrometer equipped with a monochromatic Al-Ka source operated at $1.5 \mathrm{keV}$ and $150 \mathrm{~W}$ was used for XPS measurements. The pass energy was fixed at $40 \mathrm{eV}$ for the detailed scans. A charge neutralizer was used to compensate for the surface charging during the photoemission. The Si $2 p$ signal with a binding energy of $103.3 \mathrm{eV}$ was used as an internal reference for calibration of the $\mathrm{O} 1 \mathrm{~s}, \mathrm{Fe} 2 \mathrm{p}$, and $\mathrm{Bi} 4 \mathrm{f}$ binding energy values. All binding energies reported in this work were measured with a precision of $\pm 0.2 \mathrm{eV}$. XPS data were analyzed by nonlinear curve fitting using the PeakFit 4.12 software. In all cases, a linear-type background was subtracted from the spectra and a curve fit was performed using the minimum number of Voigt G/L-type peaks that provides a good fit. In each case, the fitting routine was completed when the coefficient of determination $\left(R^{2}\right)$ value was 0.98 or higher.

\subsubsection{Catalytic measurements}

The catalytic tests were performed in a Pyrex single-pass fixed-bed reactor at atmospheric pressure and temperatures in the $350-500^{\circ} \mathrm{C}$ range. The temperature inside the reactor was monitored by a thermocouple extended into the catalyst bed. Samples in powder form $(0.3 \mathrm{~g})$ were diluted with quartz $(2 \mathrm{~g})$, loaded into the reactor, and heated to $300^{\circ} \mathrm{C}$ under He for a period of approximately $5 \mathrm{~h}$ prior to measurements. Two reaction feeds (i.e., $5.5 \% \mathrm{C}_{3} \mathrm{H}_{8} / 30 \% \mathrm{O}_{2} / 11 \% \mathrm{NH}_{3} / \mathrm{He}$ and $8 \% \mathrm{C}_{3} \mathrm{H}_{8} / 20 \% \mathrm{O}_{2} / 9 \% \mathrm{NH}_{3} / \mathrm{He}$ ) with $\mathrm{O}_{2} / \mathrm{C}_{3} \mathrm{H}_{8}$ ratios of 5.5 and 2.5 , respectively, were used to determine how catalytic properties of $\mathrm{SiO}_{2}$-supported $\mathrm{Fe}-\mathrm{Bi}$ samples in propane ammoxidation depend on the $\mathrm{O}_{2}$ content. In each case, the total volumetric 
flow rate of the reactant mixture was held at 2.7 and $9 \mathrm{ml} / \mathrm{min}$ ( $1 \mathrm{~atm}, 25^{\circ} \mathrm{C}$ ), yielding a corresponding Gas Hourly Space Velocity (GHSV) of 408 and $1360 \mathrm{~h}^{-1}$, respectively. The feed and the reaction products were analyzed with an on-line gas chromatograph (HP 5890, Agilent) equipped with TCD and FID detectors and carboxen-1000 and plot-Q columns. A carboxen-1000 column was used for the analysis of $\mathrm{CO}_{2}$, while a plot-Q column (30m, $0.53 \mathrm{~mm}$ ID, Supelco) was used for the analysis of hydrocarbons. All the lines leading to the gas chromatograph were heated at $220^{\circ} \mathrm{C}$ using heating tapes in order to avoid condensation and polymerization of the acrylonitrile. In the absence of a catalyst, there was no measurable conversion of $\mathrm{C}_{3} \mathrm{H}_{8}$. The results reported herein were obtained after steady-state conditions were reached at each temperature. In order to do so, measurements were carried out for at least $4 \mathrm{~h}$ at each temperature with 30 min intervals between the reactor effluent analysis injections. No deactivation of the catalysts was observed even after 2 days of testing at the same temperature and reproducible results were obtained at different temperatures regardless of the heating/cooling protocol used, indicating the absence of thermal deactivation either.

Propane conversion was determined as the molar amount of propane consumed over the total molar amount of propane used in the feed. Product selectivities were determined as the molar amount of each product formed divided by the molar amount of propane consumed and adjusted for differences in carbon stoichiometry (i.e., multiplied by the ratio of carbon atoms in the specific product over the number of carbon atoms in propane). Product yields were determined as the product of propane conversion multiplied by product selectivities.

\section{Results and Discussion}

Results of the catalytic measurements obtained at the GHSV of $1360 \mathrm{~h}^{-1}$ for the clusterderived $\mathrm{Fe}_{3} \mathrm{BiO}_{x} / \mathrm{SiO}_{2}$ catalyst are shown in Fig. 1, where the propane conversion and the selectivities for the various products formed are plotted as a function of reaction temperature. The limited catalytic activity observed at temperatures below $450^{\circ} \mathrm{C}$ (i.e., propane conversions below $10 \%$ ) is associated primarily with the oxidation of propane, as indicated by the formation of $\mathrm{CO}_{2}$ as the main reaction product. The formation of acrylonitrile (AcCN), acetonitrile (ACN), propene, and ethene was first detected at $420^{\circ} \mathrm{C}$. Consistent with previous literature reports [2934,36], the appearance of propene among other reaction products suggests that it may be an 
intermediate for the propane ammoxidation reaction. Both the selectivity to different products and the propane conversion continue to increase with reaction temperature. For example, the propane conversion was as high as $36 \%$ at $500^{\circ} \mathrm{C}$ and the selectivity to $\mathrm{AcCN}$ reached $49 \%$, while the yield was $18 \%$. Corresponding changes for other reaction products were evidently less prominent as $\mathrm{ACN}$, propene, and ethene selectivities remained below $10 \%$ in the $420-500^{\circ} \mathrm{C}$ temperature range.

When lower space velocities and, therefore, longer contact times were used in experiments with $\mathrm{Fe}_{3} \mathrm{BiO}_{x} / \mathrm{SiO}_{2}$, higher propane conversions were observed at the same temperature, while the selectivity to $\mathrm{AcCN}$ remained similar, resulting in higher yields, as shown in Table 1. For example, the AcCN yield increased from 7 to $19 \%$ and from 18 to $29 \%$ at reaction temperatures of 480 and $500^{\circ} \mathrm{C}$, respectively, when the GHSV was decreased from 1360 to $408 \mathrm{~h}^{-1}$. A similar trend was also observed for $\mathrm{ACN}$, since the $\mathrm{ACN}$ selectivity was not significantly affected in this case either.

Table 1. Summary of the effects of space velocity and temperature on propane conversion and product distribution over the cluster-derived $\mathrm{Fe}_{3} \mathrm{BiOx} / \mathrm{SiO}_{2}$ catalyst.

\begin{tabular}{|c|c|c|c|c|c|}
\hline $\begin{array}{c}\text { Sample/reaction } \\
\text { conditions }\end{array}$ & $\begin{array}{c}\text { Propane } \\
\text { conversion, } \\
\%\end{array}$ & $\begin{array}{c}\mathrm{AcCN} \\
\text { selectivity, } \\
\%\end{array}$ & $\begin{array}{c}\mathrm{ACN} \\
\text { selectivity, } \\
\%\end{array}$ & $\begin{array}{c}\mathrm{C}_{3} \mathrm{H}_{6} \\
\text { selectivity, } \\
\%\end{array}$ & $\begin{array}{c}\mathrm{AcCN} \\
\text { yield, } \%\end{array}$ \\
\hline $\begin{array}{c}\mathrm{FH} \mathrm{F}_{3} \mathrm{BiOx} / \mathrm{SiO}_{2}, \\
\mathrm{GHV}=1360 \mathrm{~h}^{-1} \\
\mathrm{~T}=480^{\circ} \mathrm{C}\end{array}$ & 19 & 34 & 5 & 8 & 7 \\
\hline $\begin{array}{c}\mathrm{Fe}_{3} \mathrm{BiOx} / \mathrm{SiO}_{2}, \\
\mathrm{GHSV}=408 \mathrm{~h}^{-1} \\
\mathrm{~T}=480^{\circ} \mathrm{C}\end{array}$ & 51 & 36 & 5 & 3 & 19 \\
\hline $\begin{array}{c}\mathrm{Fe} \mathrm{BiOx}_{3} / \mathrm{SiO}_{2}, \\
\mathrm{GHSV}=1360 \mathrm{~h}^{-1} \\
\mathrm{~T}=500^{\circ} \mathrm{C}\end{array}$ & 36 & 49 & 5 & 3 & 18 \\
\hline $\begin{array}{c}\mathrm{Fe} \mathrm{BiOx}_{3} / \mathrm{SiO}_{2,} \\
\mathrm{GHSV}=408 \mathrm{~h}^{-1} \\
\mathrm{~T}=500^{\circ} \mathrm{C}\end{array}$ & 59 & 48 & 4 & 4 & 29 \\
\hline
\end{tabular}




\begin{tabular}{|c|c|c|c|c|c|}
\hline $\mathrm{Fe}-\mathrm{Bi} / \mathrm{SiO}_{2}$, & 12 & $<1$ & $<1$ & 20 & $<1$ \\
$\mathrm{GHSV}=1360 \mathrm{~h}^{-1}$ & & & & & \\
$\mathrm{~T}=500^{\circ} \mathrm{C}$ & & & & & \\
\hline
\end{tabular}

A comparison was also attempted between the cluster-derived $\mathrm{Fe}_{3} \mathrm{BiO} / \mathrm{SiO}_{2}$ sample and a $\mathrm{Fe}-\mathrm{Bi} / \mathrm{SiO}_{2}$ catalyst of the same composition prepared by co-impregnation. The results collected for $\mathrm{Fe}-\mathrm{Bi} / \mathrm{SiO}_{2}$ at $500^{\circ} \mathrm{C}$ and GHSV of $1360 \mathrm{~h}^{-1}$ (Table 1) indicate a much lower propane conversion and no measurable production of either $\mathrm{AcCN}$ or $\mathrm{ACN}$, although the formation of propene was observed $(2.4 \%$ yield $)$ in addition to $\mathrm{CO}_{2}$.

The effect of the feed composition on the production of $\mathrm{AcCN}$ over $\mathrm{Fe}_{3} \mathrm{BiO} \times / \mathrm{SiO}_{2}$ was examined next. For example, at $500^{\circ} \mathrm{C}$ and GHSV of $408 \mathrm{~h}^{-1}$, a decrease in the $\mathrm{O}_{2} / \mathrm{C}_{3} \mathrm{H}_{8}$ ratio from 5.5 to 2.5 resulted in a moderate decrease of propane conversion from 59 to $47 \%$. At the same time, the AcCN selectivity increased from 48 to $59 \%$, while the AcCN yield (28\%) remained unchanged. The complete results collected at these conditions are shown in Fig. 2.

Typical HAADF HRSTEM images collected for a cluster-derived $\mathrm{Fe}_{3} \mathrm{BiO} / \mathrm{SiO}_{2}$ sample that was used for propane ammoxidation at $500^{\circ} \mathrm{C}$ are shown in Fig. 3. Highly dispersed particles less than $2 \mathrm{~nm}$ in size constitute the majority of particles present on these images. The particle size distribution obtained for this sample is relatively narrow with approximately $96 \%$ of the particles being in the size range of 0.5-2.0 nm. Several particles with sizes in the 2.5-4.5 nm range can be also found in HRSTEM images. While the fraction of these larger particles is relatively small and does not exceed $4 \%$, their contribution to an average particle size is significant, as the surface-averaged size of the particles calculated from these data was found to be of approximately $2 \mathrm{~nm}$ (Fig. 4). Energy dispersive X-ray spectroscopy (EDS) measurements performed on random particles of different sizes shows the presence of both $\mathrm{Fe}$ and $\mathrm{Bi}$ in these particles with atomic concentrations of approximately 75 and $25 \%$, respectively, yielding approximately a $3: 1 \mathrm{Fe} / \mathrm{Bi}$ atomic ratio, which is consistent with the $\mathrm{Fe} / \mathrm{Bi}$ ratio found in the cluster precursor complex.

In addition, to determine the elemental distribution of $\mathrm{Bi}$ and $\mathrm{Fe}$ on the surface of $\mathrm{Fe}_{3} \mathrm{BiO} x / \mathrm{SiO}_{2}$, spatially resolved EDS measurements were carried out on a relatively wide sample area (around 0.08 square micrometers). Figs. 5A and 5B show the relevant EDS 
chemical maps of the $\mathrm{Bi} \mathrm{L} \alpha$ and $\mathrm{Fe} \mathrm{K} \alpha$ characteristic X-rays, respectively, acquired at a pixel size of $10 \mathrm{~nm}$. These images are unfiltered, representing the raw intensities of the characteristic $\mathrm{Bi}$ and $\mathrm{Fe}$ edges at each point in the map. A comparison of these maps shows that the bright areas enriched in Fe in Fig. 5B closely correspond to the areas enriched in $\mathrm{Bi}$ in Fig. 5A. This further suggests that $\mathrm{Fe}$ and $\mathrm{Bi}$ are closely associated on the surface of this catalytic material.

To clarify the nature of particles formed in the spent $\mathrm{Fe}_{3} \mathrm{BiO}_{x} / \mathrm{SiO}_{2}$ sample, the surface of this material was examined by X-ray photoelectron spectroscopy (XPS) and the spectra collected for the $\mathrm{O} 1 \mathrm{~s}, \mathrm{Fe} 2 \mathrm{p}$, and $\mathrm{Bi} 4 \mathrm{f}$ regions are shown in Figs. 6-8. The $\mathrm{O} 1 \mathrm{~s}$ spectrum includes two components with binding energies of 532.9 and $530.3 \mathrm{eV}$ (Fig. 6). Consistent with previous literature reports [42], a relatively strong $\mathrm{O} 1 \mathrm{~s}$ peak at $532.9 \mathrm{eV}$ originates from Si-O contributions of the $\mathrm{SiO}_{2}$ support. In agreement with such an assignment, the $\mathrm{O} / \mathrm{Si}$ atomic ratio for this peak was found to be of approximately 2.0. A weaker $\mathrm{O} 1 \mathrm{~s}$ contribution at $530.3 \mathrm{eV}$ clearly represents the species formed on the $\mathrm{SiO}_{2}$ surface. The specific assignment for this peak is less certain since differences in $\mathrm{O} 1 \mathrm{~s}$ binding energies reported previously for various $\mathrm{Fe}$ oxides (i.e., 529.9-530.9 eV) [43], $\mathrm{Bi}_{2} \mathrm{O}_{3}(529.4 \mathrm{eV})$ [44], and $\mathrm{FeBiO}_{3}(529.5 \mathrm{eV}$ ) [45] species are small and, therefore, $\mathrm{O}$ 1s peaks originating from $\mathrm{Fe}-\mathrm{O}, \mathrm{Bi}-\mathrm{O}$, and $\mathrm{Fe}-\mathrm{O}-\mathrm{Bi}$ are expected to overlap if any combinations of such species are formed on the support surface. Regardless of this uncertainty, the presence of this peak in the XPS spectrum indicates that the particles observed on the surface of the spent $\mathrm{Fe}_{3} \mathrm{BiO}_{\mathrm{x}} / \mathrm{SiO}_{2}$ material by HRSTEM are oxides in nature.

The Bi $4 \mathrm{f}$ region can be fitted with a pair of peaks with FWHM values of $1.7 \mathrm{eV}$, a spin-orbit split of $5.3 \mathrm{eV}$, and binding energies of 159.3 and $164.6 \mathrm{eV}$ which correspond to $\mathrm{Bi} 4 \mathrm{f}_{7 / 2}$ and $\mathrm{Bi}$ $4 \mathrm{f}_{5 / 2}$ core level emissions, respectively (Fig. 7). These binding energies are slightly higher than those reported previously for $\mathrm{Bi}_{2} \mathrm{O}_{3}$ (i.e., 158.8 and $164.2 \mathrm{eV}$ ) [46] but match closely with the $\mathrm{Bi}$ $4 \mathrm{f}_{7 / 2}$ and $\mathrm{Bi} 4 \mathrm{f}_{5 / 2}$ binding energies reported for various mixed oxides, including $\mathrm{FeBiO}_{3}$ (i.e., 159.1 and $164.4 \mathrm{eV}$, respectively) [47]. While higher binding energies of $\mathrm{Bi}$ in the latter case can be explained by electron transfer from the Bi cations towards other components of mixed oxides [46], the $\mathrm{Bi} 4 \mathrm{f}_{7 / 2}$ and $\mathrm{Bi} 4 \mathrm{f}_{5 / 2}$ binding energies determined from our spectra are consistent with $\mathrm{Bi}^{3+}$ cations being present on the surface of the spent $\mathrm{Fe}_{3} \mathrm{BiO} / \mathrm{SiO}_{2}$ material, as no any contributions from $\mathrm{Bi}^{5+}$ cations (expected at 161.5 and $167.0 \mathrm{eV}$ for $4 \mathrm{f}_{7 / 2}$ and $4 \mathrm{f}_{5 / 2}$ core level emissions, respectively) can be observed in XPS spectra. 
The Fe $2 p$ XPS region is more complex and includes besides $2 p_{3 / 2}$ and $2 p_{1 / 2}$ spin-orbit doublet components the corresponding satellite peaks at 718.2 and $731.7 \mathrm{eV}$, respectively (Fig. 8). Moreover, minimum two components is required to include in the fit for each $\mathrm{Fe} 2 \mathrm{p}_{3 / 2}$ and $\mathrm{Fe}$ $2 p_{1 / 2}$ emission line in order to achieve a $R^{2}$ value of 0.98 or higher. As a result, two types of $\mathrm{Fe}$ ions can be identified in the spectrum with $\mathrm{Fe} 2 \mathrm{p}_{3 / 2}$ and $\mathrm{Fe} 2 \mathrm{p}_{1 / 2}$ binding energies of 710.6/713.0 $\mathrm{eV}$ and 723.9/726.1 eV, respectively, and a spin-orbit split of approximately13.2 eV. These binding energies are fully consistent with those reported in the literature $[43,45,46]$ for $\mathrm{Fe}^{3+}$ ions in $\mathrm{FeO}(\mathrm{OH}), \mathrm{Fe}_{3} \mathrm{O}_{4}, \mathrm{Fe}_{2} \mathrm{O}_{3}$, and $\mathrm{FeBiO}_{3}$ compounds. Since the presence of satellite peaks is typical for $\mathrm{Fe} 2 \mathrm{p}_{3 / 2}$ and $\mathrm{Fe} 2 \mathrm{p}_{1 / 2}$ emission lines of $\mathrm{Fe}^{3+}$ ions and contributions from $\mathrm{Fe}^{2+}$ ions (expected at $709.5 \mathrm{eV}$ ) cannot be found in the spectrum, we can conclude with confidence that only $\mathrm{Fe}^{3+}$ ions are present on the surface of the spent $\mathrm{Fe}_{3} \mathrm{BiO}_{x} / \mathrm{SiO}_{2}$ material. These $\mathrm{Fe}^{3+}$ ions are obviously not identical since both the $\mathrm{Fe} 2 \mathrm{p}_{3 / 2}$ and $\mathrm{Fe} 2 \mathrm{p}_{1 / 2}$ core level emission lines split into two components.

Since XPS provides average information from the surface, several assignments are possible. For example, one could suggest that the $\mathrm{Fe} 2 \mathrm{p}_{3 / 2}$ and $\mathrm{Fe} 2 \mathrm{p}_{1 / 2}$ peaks with binding energies of 710.6 and $723.9 \mathrm{eV}$, respectively, represent Fe-O-Bi species, while the second set of $\mathrm{Fe} 2 \mathrm{p}_{3 / 2}$ and $\mathrm{Fe} 2 \mathrm{p}_{1 / 2}$ peaks with binding energies of 713.0 and $726.1 \mathrm{eV}$, respectively, originates from $\mathrm{Fe}^{3+}$ cations not interacting with $\mathrm{Bi}$. In other words, such an assignment suggests that not all oxide particles formed on the surface of $\mathrm{SiO}_{2}$ incorporate both the $\mathrm{Fe}$ and $\mathrm{Bi}$ ions but at least some of them incorporate only Fe ions.

Alternatively, one can suggest that all particles formed on the $\mathrm{SiO}_{2}$ surface consist of mixed FeBi oxides but $\mathrm{Fe}^{3+}$ ions in these particles have two different coordination environments. This suggestion is similar to what have been reported previously for several pure Fe oxides and $\mathrm{FeBiO}_{3}$ nanoparticles. For example, $\mathrm{Fe}^{3+}$ ions in octahedral and tetrahedral coordination with characteristic $\mathrm{Fe} 2 \mathrm{p}_{3 / 2}$ binding energies in the 710.2-712.3 $\mathrm{eV}$ and 712.9-713.7 eV range, respectively, were found to be present in $\mathrm{Fe}_{3} \mathrm{O}_{4}$ and $\mathrm{Fe}_{2} \mathrm{O}_{3}$ [43]. Likewise, it has been reported that the $\mathrm{Fe} 2 \mathrm{p}_{3 / 2}$ region of $\mathrm{FeBiO}_{3}$ nanoparticles splits into two components with binding energies of 710.3 and $712.1 \mathrm{eV}$, consistent with the presence of Fe-O-Bi links in which $\mathrm{Fe}^{3+}$ ions have two different coordination environments [45]. 
In attempts to narrow the assignment choices for the $\mathrm{Fe} 2 \mathrm{p}$ region and to determine the composition of particles formed on the $\mathrm{SiO}_{2}$ surface more precisely, XPS spectra in $\mathrm{O} 1 \mathrm{~s}, \mathrm{Fe} 2 \mathrm{p}$, and $\mathrm{Bi} 4 \mathrm{f}$ regions were quantified using peak areas and atomic sensitivity factors that were included in the Kratos software by the manufacture. The results obtained indicate that particles formed on the surface of the spent $\mathrm{Fe}_{3} \mathrm{Bi} / \mathrm{SiO}_{2}$ sample consist of $61.6 \% \mathrm{O}, 27.7 \% \mathrm{Fe}$, and $10.7 \%$ $\mathrm{Bi}$, yielding a $\mathrm{Fe} / \mathrm{Bi}$ atomic ratio of 2.6 and a net composition of surface species of approximately $\mathrm{Fe}_{2.6} \mathrm{BiO}_{5.8}$. The $\mathrm{Fe} / \mathrm{Bi}$ atomic ratio determined from XPS is fairly close to a $\mathrm{Fe} / \mathrm{Bi}$ atomic ratio of 3 estimated from EDS measurements, suggesting that the $\mathrm{Fe} / \mathrm{Bi}$ ratio remains nearly unchanged when the cluster precursor is transformed into a mixed $\mathrm{FeBi}$ oxide on the surface of silica under reaction conditions. Taking into account that the $\mathrm{Fe}$ and $\mathrm{Bi}$ ions both are in the $3+$ oxidation state, the net composition of the surface species thus formed can be further approximated as $\mathrm{Fe}_{3} \mathrm{BiO}_{6}$ to balance the overall charge. However, since $\mathrm{FeBiO}_{3}$ is the most common composition representing mixed $\mathrm{FeBi}$ oxides [45,46], one could also suggest that $\mathrm{Fe}_{3} \mathrm{BiO}_{6}$ species can be represented by a 1:1 ratio of $\mathrm{FeBiO}_{3}$ and $\mathrm{Fe}_{2} \mathrm{O}_{3}$. While such a suggestion clearly assumes the existence of two types of $\mathrm{Fe}^{3+}$ ions due to the presence of $\mathrm{Fe}-\mathrm{O}-\mathrm{Bi}$ and $\mathrm{O}-\mathrm{Fe}-$ $\mathrm{O}$ on the support surface and is consistent with fitting results for the Fe $2 p$ region, it is also assumes that the atomic ratio between $\mathrm{Fe}$ species of $\mathrm{Fe}_{2} \mathrm{O}_{3}$ and those of $\mathrm{FeBiO}_{3}$ must be 2:1. In contrast to this expectation, our results show a 1:1 ratio between $\mathrm{Fe}^{3+}$ species with characteristic $\mathrm{Fe} 2 \mathrm{p}_{3 / 2}$ binding energies of 713.0 and $710.6 \mathrm{eV}$, strongly suggesting that this is not the case. Therefore, it is more likely that particles observed on the surface of $\mathrm{SiO}_{2}$ in the spent $\mathrm{Fe}_{3} \mathrm{BiO} / \mathrm{SiO}_{2}$ material consists of a pure $\mathrm{Fe}_{3} \mathrm{BiO}_{6}$ mixed oxide in which $\mathrm{Fe}^{3+}$ ions have two distinct coordination environments. Our attempts to clarify further the structure of these particles by XRD were not successful due to their small sizes.

For comparison purposes, XPS measurements were also performed over the spent $\mathrm{Fe}-\mathrm{Bi} / \mathrm{SiO}_{2}$ material prepared by co-impregnation. The spectra collected for the $\mathrm{O} 1 \mathrm{~s}, \mathrm{Fe} 2 \mathrm{p}$, and $\mathrm{Bi}$ if regions are shown in Figs. 9-11. The O 1s spectrum includes two components with binding energies of 532.8 and $530.0 \mathrm{eV}$ (Fig. 9). The former peak clearly represents the support oxygen, as the $\mathrm{O} / \mathrm{Si}$ atomic ratio of 2.1 for this peak is consistent with the $\mathrm{SiO}_{2}$ stoichiometry. As we discussed above, the $\mathrm{O} 1 \mathrm{~s}$ peak at $530.0 \mathrm{eV}$ most likely represents Fe-O, Bi-O, and Fe-O-Bi contributions of the oxide species formed on the $\mathrm{SiO}_{2}$ surface. Similar to the case of the clusterderived sample, the Bi $4 \mathrm{f}$ region includes a pair of peaks with binding energies of 159.2 and 
$164.5 \mathrm{eV}$ assigned to $\mathrm{Bi} 4 \mathrm{f}_{7 / 2}$ and $\mathrm{Bi} 4 \mathrm{f}_{5 / 2}$ core level emissions, respectively (Fig. 10). Furthermore, two types of Fe ions can also be identified in the Fe 2 p spectrum of this sample with Fe $2 p_{3 / 2}$ and Fe $2 p_{1 / 2}$ binding energies of 710.6/713.2 eV and 723.9/726.0 eV, respectively, together with the corresponding satellite peaks at 718.2 and $731.5 \mathrm{eV}$, respectively (Fig. 11).

A comparison of these data with those included in Figs. 6-8 further shows that the coimpregnated sample has the set of peaks in the $\mathrm{Bi} 4 \mathrm{f}$ and $\mathrm{Fe} 2 \mathrm{p}$ regions with binding energies closely matching the corresponding binding energies of the cluster-derived sample. This result suggests that surface species of similar nature are formed in both cases and these species incorporate iron and bismuth, both of which are in +3 oxidation state.

However, some substantial differences between co-impregnated and cluster-derived samples were also observed. For example, Table 2 shows a comparison of the $\mathrm{O} / \mathrm{Si}, \mathrm{Fe} / \mathrm{Si}$, and $\mathrm{Bi} / \mathrm{Si}$ atomic intensity ratios for these two materials. It has been shown previously that atomic intensity ratios of different peaks in XPS spectra are directly related to the dispersion of metal oxide species formed [48,49]. The larger the ratio, the more dispersed the oxide phase $[48,49]$. As can be noted from data of Table 2, the $\mathrm{O} / \mathrm{Si}, \mathrm{Fe} / \mathrm{Si}$, and $\mathrm{Bi} / \mathrm{Si}$ atomic intensity ratios characterizing the cluster-derived $\mathrm{Fe}_{3} \mathrm{BiO} / \mathrm{SiO}_{2}$ sample are significantly larger than those calculated for the co-impregnated $\mathrm{Fe}-\mathrm{Bi} / \mathrm{SiO}_{2}$ sample, strongly suggesting that the surface species formed in the former case are better dispersed.

Table 2. XPS atomic intensity ratios of samples used for propane ammoxidation.

\begin{tabular}{|c|c|c|c|}
\hline Sample & $\mathrm{O} / \mathrm{Si}$ & $\mathrm{Fe} / \mathrm{Si}$ & $\mathrm{Bi} / \mathrm{Si}$ \\
\hline $\mathrm{Fe}_{3} \mathrm{BiO} / \mathrm{SiO}_{2}$ & 0.17 & 0.08 & 0.03 \\
\hline $\mathrm{Fe}-\mathrm{Bi} / \mathrm{SiO}_{2}$ & 0.01 & 0.03 & 0.005 \\
\hline
\end{tabular}

It is further evident that the $\mathrm{Fe} / \mathrm{Bi}$ ratio characterizing the co-impregnated $\mathrm{Fe}-\mathrm{Bi} / \mathrm{SiO}{ }_{2}$ sample is approximately 6 , which is higher than the $\mathrm{Fe} / \mathrm{Bi}$ ratio of 2.7 estimated for the cluster-derived sample. This result clearly indicates that the 3:1 Fe/Bi ratio initially intended for surface species in the co-impregnated material does not hold and in fact, the surface species formed are enriched 
with iron. Therefore, we can infer that the dispersion of surface species formed and the $\mathrm{Fe} / \mathrm{Bi}$ ratio in these species are two important factors that govern ammoxidation activity of this type materials, considering that a bifunctional-type of mechanism is involved in the ammoxidation of the propane [3].

\section{Conclusions}

Our results have shown that the cluster-derived $\mathrm{Fe}_{3} \mathrm{BiO}_{\mathrm{x}} / \mathrm{SiO}_{2}$ material prepared from the $\left[\mathrm{Et}_{4} \mathrm{~N}\right]\left[\mathrm{Fe}_{3}(\mathrm{CO})_{10}\left(\mu_{3}-\mathrm{Bi}\right)\right]$ precursor is an effective catalyst for the ammoxidation of propane at temperatures above $500^{\circ} \mathrm{C}$. Nearly uniform particles with an average size of approximately $2 \mathrm{~nm}$ are formed on the surface of this material under reaction conditions. EDS and XPS measurements indicate that these particles incorporate both the $\mathrm{Fe}$ and $\mathrm{Bi}$ components with a 3:1 $\mathrm{Fe} / \mathrm{Bi}$ atomic ratio and both of these elements are in the +3 oxidation state in the active material. The cluster-derived $\mathrm{Fe}_{3} \mathrm{BiO}$ x $/ \mathrm{SiO}_{2}$ sample performs moderately better than $\mathrm{FeSb}$ oxide catalysts used for propane ammoxidation [29-33], but it is not as effective as the $\mathrm{MoV}(\mathrm{Nb}, \mathrm{Ta})(\mathrm{Te}, \mathrm{Sb}) \mathrm{O}$ combinations also used for the same reaction $[3,26]$. The presence of propene in the effluent suggests that propene may be an intermediate in the catalytic process, as has been also recognized by others [29-34,36].

\section{Acknowledgements}

This research was supported by the National Science Foundation CHE-1111496 (RDA).

\section{References}

[1] R.K. Grasselli, in: G. Ertl, H. Knozinger, J. Weitkamp (Eds.), Handbook of Heterogeneous Catalysis, VCH Publishers, Weinheim, 1997, vol. 5, pp. 2302-2326.

[2] J.F. Brazdil, in: A. Seidel (Ed.), Kirk-Othmer Encyclopedia of Chemical Technology, WileyInterscience, New York, 1991, pp. 397-414.

[3] R.K. Grasselli, C.G. Lugmair, A.F. Volpe Jr., Top. Catal. 54 (2011) 595-604.

[4] T.A. Hanna, Coord. Chem. Rev. 248 (2004) 429-440.

[5] W.A. Goddard III, K. Chenoweth, S. Pudar, A.C.T. van Duin, M.-J. Cheng, Top. Catal. 50 (2008) 2-18.

[6] Y.H. Jang, W.A. Goddard III, J. Phys. Chem. B 106 (2002) 5997-6013. 
[7] A. Getsoian, V. Shapovlov, A.T. Bell, J. Phys. Chem. C 117 (2013) 7123-7137.

[8] A.K. Rappé, Molec. Phys. 102 (2004) 289-299.

[9] S. Pudar, J. Oxgaard, K. Chenoweth, A.C.T. van Duin, W.A. Goddard III, J. Phys. Chem. C 111 (2007) 16405-16415.

[10] D. Dumitriu, R. Bârjega, L. Frunza, D. Macovei, T. Hu, Y. Xie, V.I. Pârvulescu, S. Kaliaguine, J. Catal. 219 (2003) 337-351.

[11] J. Zhao, G. Qian, F. Li, J. Zhu, S. Ji, L. Li, Chin. J. Catal. 33 (2012) 771-776.

[12] G. Qian, D. Ji, G. Lu, R. Zhao, Y. Qi, J. Suo, J. Catal. 232 (2005) 378-385.

[13] R.K. Grasselli, Top. Catal. 21 (2002) 79-88.

[14] R.K. Grasselli, Catal. Today 99 (2005) 23-31.

[15] Y. Ishii, S. Sakaguchi, T. Iwahama, Adv. Synth. Catal. 343 (2001) 393-427.

[16] T. Punniyamurthy, T.; S. Velusamy, J. Iqbal, Chem. Rev. 105 (2005) 2329-2363.

[17] M.A. Soria, P. Ruiz, E.M. Gaigneaux, Catal. Today 203 (2013) 40-47.

[18] C. O’Neill, E.E. Wolf, Catal. Today 156 (2010) 124-131.

[19] M.M. Bettahar, G. Costentin, L. Savary, J.C. Lavalley, Appl. Catal. A 145 (1996) 1-48.

[20] R.K. Grasselli, C.G. Lugmair, A.F. Volpe, A. Andersson, J.D. Burrington, Catal. Today 157 (2010) 33-38.

[21] M. Vaarkamp, U. Takashi, Appl. Catal. A 174 (1998) 99-107.

[22] A. Kaddouri, C. Mazzocchia, E. Tempesti, Appl. Catal. A 180 (1999) 271-275.

[23] H.W. Zanthoff, S. Schaefer, G.U. Wolf, Appl. Catal. A 164 (1997) 105-117.

[24] P. Biswas, J. Woo, V.V. Guliants, Catal. Commun. 12 (2010) 58-63.

[25] I. Ramli, P. Botella, F. Ivars, W.P. Meng, S.M.M. Zawawi, H.A. Ahangar, S. Hernandez, J.M.L. Nieto, J. Molec. Catal. A 342-343 (2011) 50-57.

[26] R.K. Grasselli, J.D. Burington, D.J. Buttrey, P. DeSanto Jr., C.G. Lugmair, A.F. Volpe Jr., T. Weingand, Top. Catal. 23 (2003) 5-22.

[27] R.K. Grasselli, A.F. Volpe Jr., Top. Catal. 57 (2014) 1124-1137.

[28] J. Yu, Y. Xu, V.V. Guliants, Top. Catal. 57 (2014) 1145-1151.

[29] R. Catani, G. Centi, F. Trifiro, R.K. Grasselli, Ind. Eng. Chem. Res. 31 (1992) 107-119.

[30] M.O. Guerrero-Perez, M.A. Pena, J.L.G. Fierro, M.A. Banares, Ind. Eng. Chem. Res. 45 (2006) 4537-4543.

[31] H.-W. Zanthoff, S.A. Bucholz, Catal. Lett. 49 (1997) 213-217. 
[32] S. Albonetti, G. Blanchard, P. Buratin, T.J. Cassidy, S. Masetti, F. Trifiro, Catal. Lett. 45 (1997) 119-123.

[33] G. Centi, F. Marchi, Stud. Surf. Sci. Catal. 101 (1996) 277-286.

[34] M. Bowker, C.R. Bicknell, P. Kerwin, Appl. Catal. A 136 (1996) 205-229.

[35] M.D. Allen, G.J. Hutching, M. Bowker, Appl. Catal. A 217 (2001) 33-39.

[36] C. Zhuang, C.R.A. Catlow, J. Phys. Chem. C 112 (2008) 9783-9797.

[37] K. Miyake, H. Oka, H. Sakamoto, Y. Harano, T. Imoto, J. Chem. Soc., Japan 2 (1972) 284-289.

[38] H. Oka, K. Miyake, Y. Harano, T. Imoto, J. Appl. Chem. Biotechnol. 25 (1975) 663-670.

[39] R.D. Adams, M. Chen, G. Elpitiya, M.E. Potter, R. Raja, ACS Catal. 3 (2013) 3106-3110.

[40] R. Raja, R.D. Adams, D.A. Blom, W.C. Pearl Jr., E. Gianotti, J.M. Thomas, Langmuir 25 (2009) 7200-7204.

[41] K.H. Whitmire, C.B. Lagrone, M.R. Churchill, J.C. Fettinger, L.V. Biondi, Inorg. Chem. 23 (1984) 4227-4232.

[42] P. Yang, L. Liu, J. Mo, W. Yang, Semicond. Sci. Technol. 25 (2010) 045017/1-045017/4.

[43] S. Poulin, R. França, L. Moreau-Bélanger, E. Sacher, J. Phys. Chem. C 114 (2010) 10711-10718.

[44] D. Barreca, F. Morazzoni, G.A. Rizzi, R. Scotti, E. Tondello, Phys. Chem. Chem. Phys. 3 (2001) 1743-1749.

[45] T. Gao, Z. Chen, Y. Zhu, F. Niu, Q. Huang, L. Qin, X. Sun, Y. Huang, Mater. Res. Bull. 59 (2014) 6-12.

[46] Y. Schuhl, H. Baussart, R. Delobel, M. Le Bras, J.-M. Leroy, J. Chem. Soc. Faraday Trans. 79 (1983) 2055-2069.

[47] K. Jiang, J.J. Zhu, J. G. Wu, J. Sun, Z.G. Hu, J.H. Chu, ACS Appl. Mater. Interfaces 3 (2011) 4844-4852.

[48] Y. Okamoto, T. Imanaka, S. Teranishi, J. Phys. Chem. 85 (1981) 3798-3805.

[49] B.M. Reddy, B. Chowdhury, P.G. Smirniotis, Appl. Catal. A 211 (2001) 19-30. 
Figure 1. Propane conversion and product selectivities for the ammoxidation of propane over a cluster-derived $\mathrm{Fe}_{3} \mathrm{BiOx} / \mathrm{SiO}_{2}$ catalyst as a function of reaction temperature (Feed composition: $5.5 \% \mathrm{C}_{3} \mathrm{H}_{8} / 30 \% \mathrm{O}_{2} / 11 \% \mathrm{NH}_{3} / \mathrm{He}$ balance; GHSV $\left.=1360 \mathrm{~h}^{-1}\right)$.

Figure 2. Propane conversion and product selectivities for the ammoxidation of propane over a cluster-derived $\mathrm{Fe}_{3} \mathrm{Bi} / \mathrm{SiO}_{2}$ catalyst as a function of reaction temperature (Feed composition: $8 \% \mathrm{C}_{3} \mathrm{H}_{8} / 20 \% \mathrm{O}_{2} / 9 \% \mathrm{NH}_{3} / \mathrm{He}$ balance; GHSV $=408 \mathrm{~h}^{-1}$ ).

Figure 3. HAADF HRSTEM images of a cluster-derived $\mathrm{Fe}{ }_{3} \mathrm{BiOx} / \mathrm{SiO}_{2}$ catalyst that was used for propane ammoxidation at $500^{\circ} \mathrm{C}$.

Figure 4. Particle size distribution characterizing a cluster-derived $\mathrm{Fe}_{3} \mathrm{BiOx} / \mathrm{SiO}_{2}$ catalyst that was used for propane ammoxidation at $500^{\circ} \mathrm{C}$.

Figure 5. EDS maps of the $\mathrm{Bi} L \alpha(\mathrm{A})$ and $\mathrm{Fe} \mathrm{K} \alpha(\mathrm{B})$ characteristic $\mathrm{X}$-rays acquired at a pixel size of $10 \mathrm{~nm}$ for a cluster-derived $\mathrm{Fe}_{3} \mathrm{BiOx} / \mathrm{SiO}_{2}$ catalyst that was used for propane ammoxidation at $500^{\circ} \mathrm{C}$.

Figure 6. $\mathrm{O} 1 \mathrm{~s}$ region of the XPS spectrum of a cluster-derived $\mathrm{Fe}_{3} \mathrm{Bi} / \mathrm{SiO}_{2}$ catalyst used for propane ammoxidation at $500^{\circ} \mathrm{C}$ (solid line) and deconvolution results (dotted line).

Figure 7. $\mathrm{Bi} 4 \mathrm{f}$ region of the XPS spectrum of a cluster-derived $\mathrm{Fe}_{3} \mathrm{Bi} / \mathrm{SiO}_{2}$ catalyst used for propane ammoxidation at $500^{\circ} \mathrm{C}$ (solid line) and deconvolution results (dotted line).

Figure 8. Fe $2 p$ region of the XPS spectrum of a cluster-derived $\mathrm{Fe}_{3} \mathrm{Bi} / \mathrm{SiO}_{2}$ catalyst used for propane ammoxidation at $500^{\circ} \mathrm{C}$ (solid line) and deconvolution results (dotted line).

Figure 9. $\mathrm{O} 1 \mathrm{~s}$ region of the XPS spectrum of a co-impregnated $\mathrm{Fe}-\mathrm{Bi} / \mathrm{SiO}_{2}$ catalyst used for propane ammoxidation at $500^{\circ} \mathrm{C}$ (solid line) and deconvolution results (dotted line).

Figure 10. $\mathrm{Bi} 4 \mathrm{f}$ region of the XPS spectrum of a co-impregnated $\mathrm{Fe}-\mathrm{Bi} / \mathrm{SiO}_{2}$ catalyst used for propane ammoxidation at $500^{\circ} \mathrm{C}$ (solid line) and deconvolution results (dotted line).

Figure 11. Fe $2 p$ region of the XPS spectrum of a co-impregnated $\mathrm{Fe}-\mathrm{Bi} / \mathrm{SiO}_{2}$ catalyst used for propane ammoxidation at $500^{\circ} \mathrm{C}$ (solid line) and deconvolution results (dotted line). 
$\mathrm{C}_{3} \mathrm{H}_{8}+\mathrm{O}_{2}+\mathrm{NH}_{3} \quad \mathrm{H}_{2} \mathrm{C}=\mathrm{CH}(\mathrm{CN})$

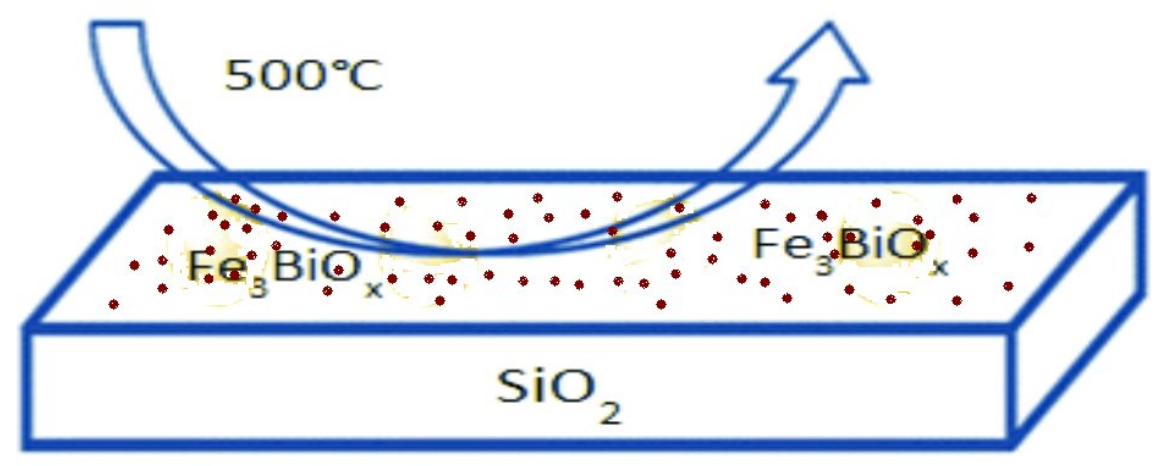


- Cluster-derived $\mathrm{Fe}_{3} \mathrm{BiO}_{\mathrm{x}} / \mathrm{SiO}_{2}$ is an effective catalyst for propane ammoxidation.

- $2 \mathrm{~nm}$ particles are formed on the surface of this material under reaction conditions.

- These particles incorporate $\mathrm{Fe}^{3+}$ and $\mathrm{Bi}^{3+}$ components with a 3:1 $\mathrm{Fe} / \mathrm{Bi}$ atomic ratio.

- Co-impregnated $\mathrm{Fe}-\mathrm{Bi} / \mathrm{SiO}_{2}$ is low active for propane ammoxidation.

- Larger particles with surfaces enriched with Fe are formed in this material. 


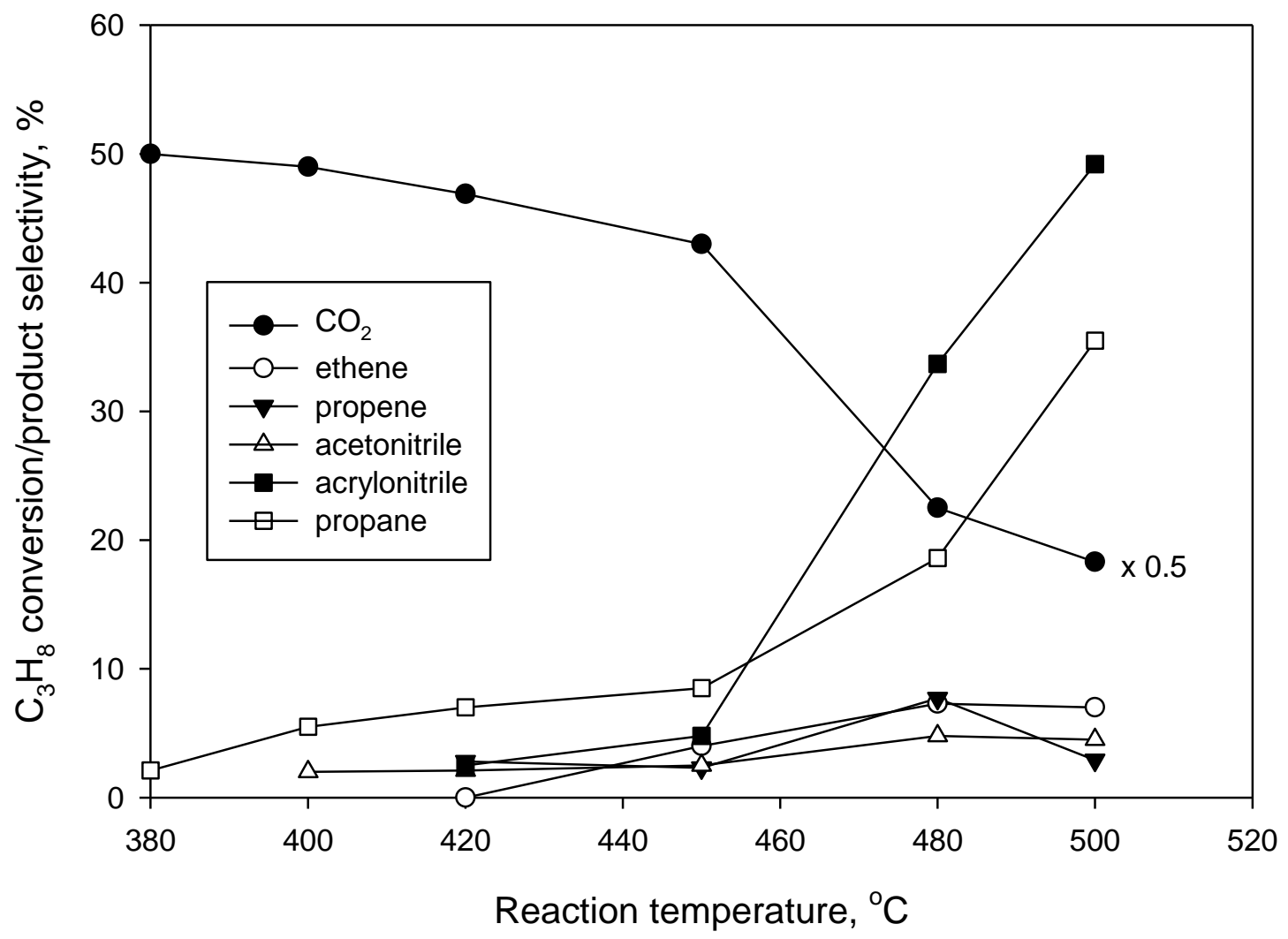

Fig. 1. Adams et al. 


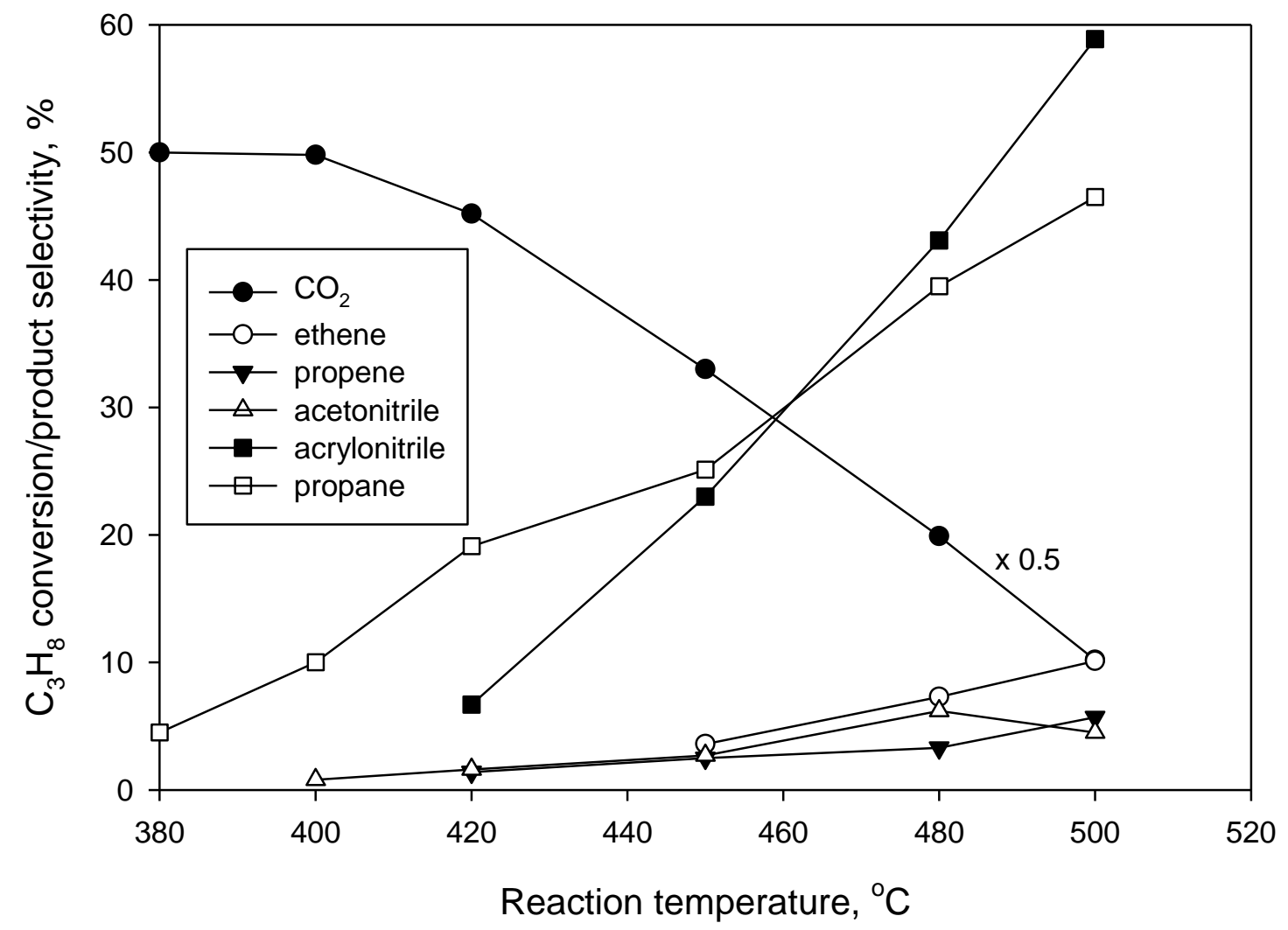

Fig. 2. Adams et al. 

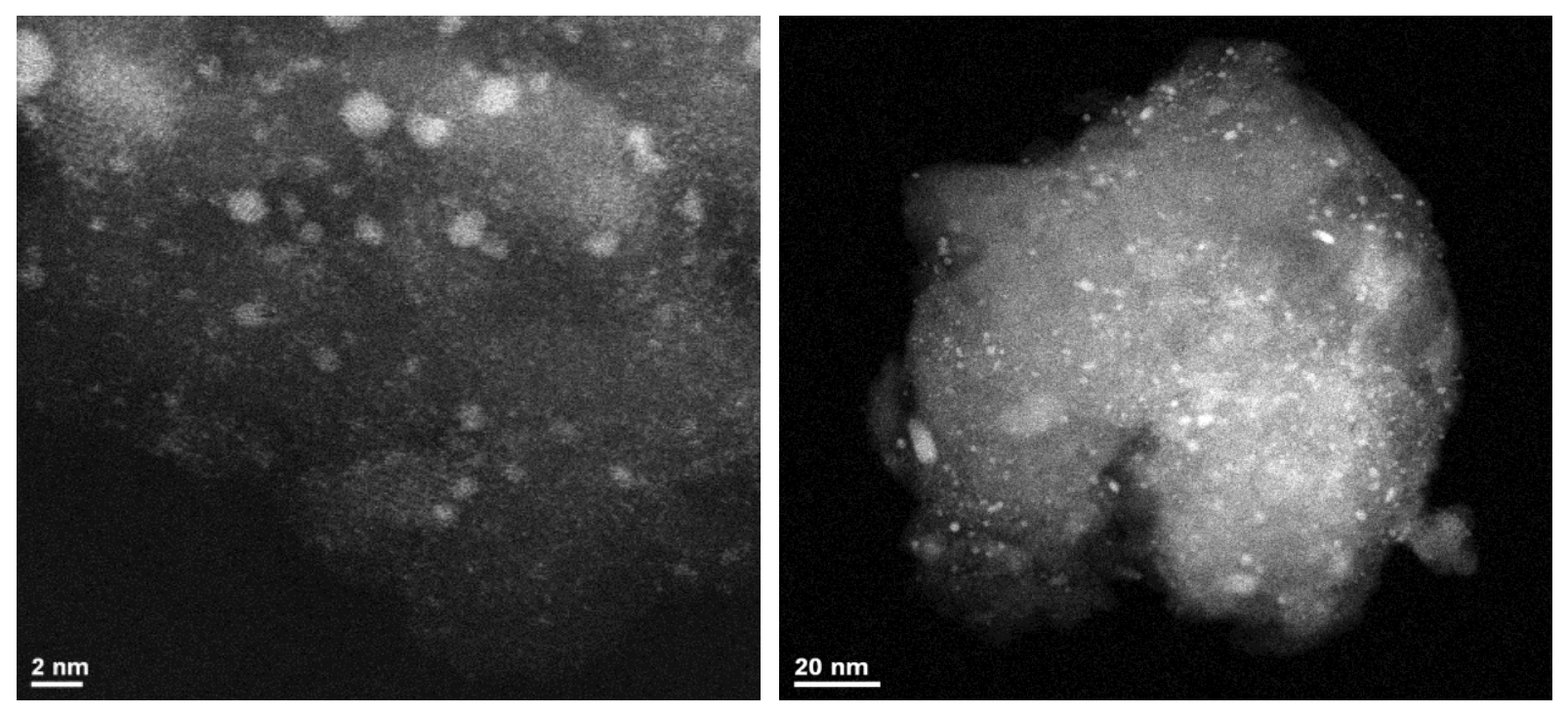

Fig. 3. Adams et al. 


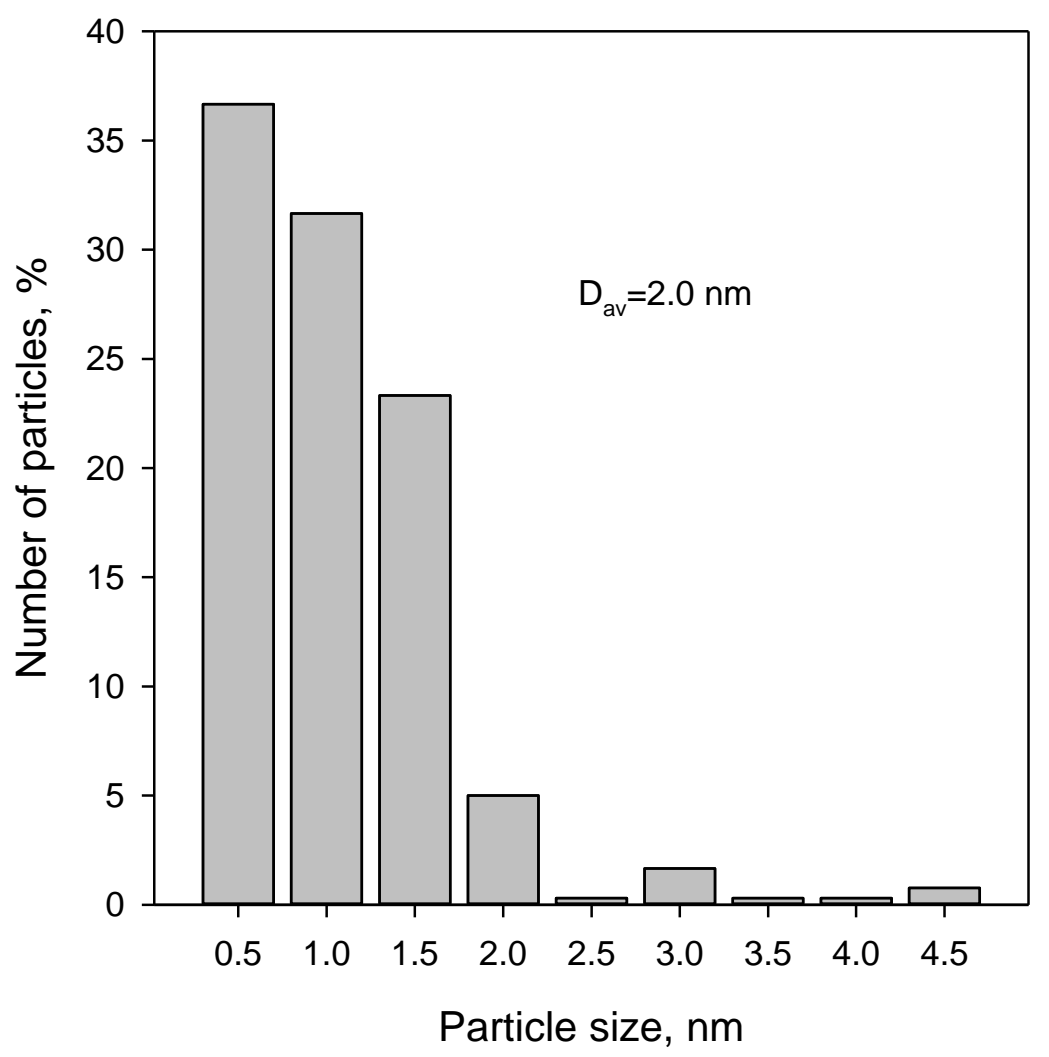

Fig. 4. Adams et al. 


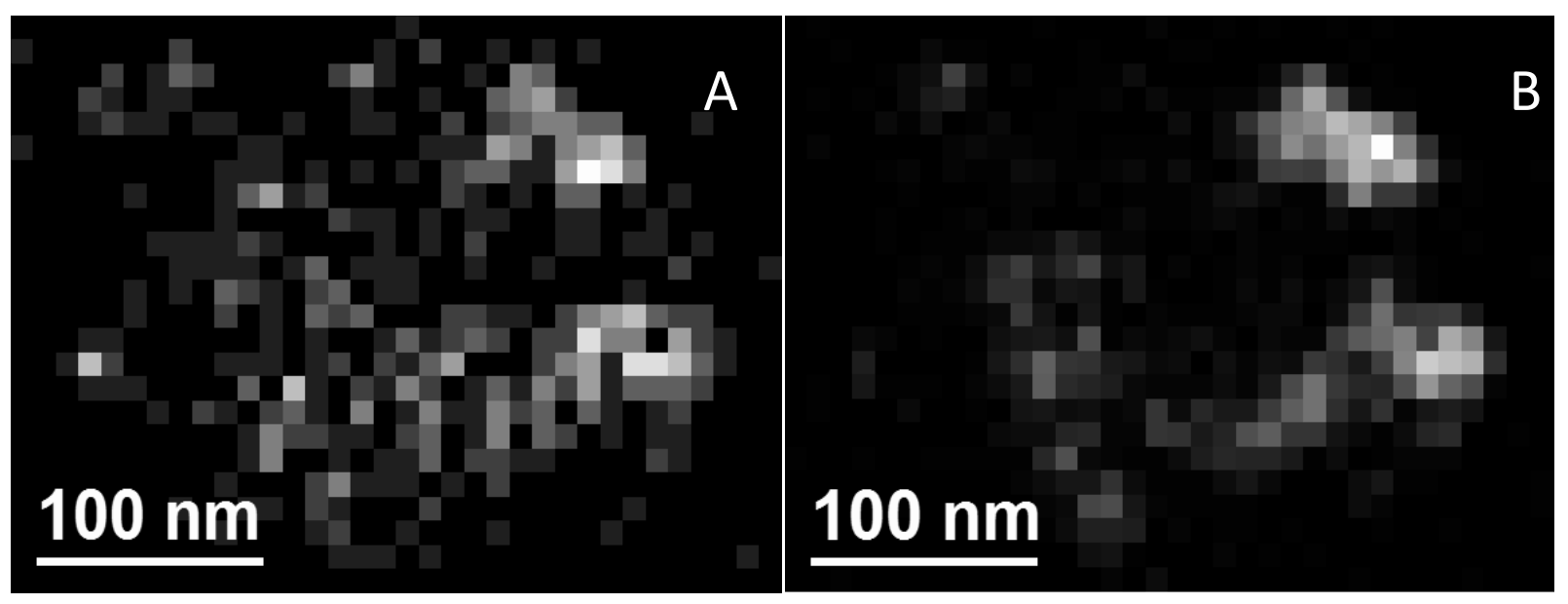

Fig. 5. Adams et al. 


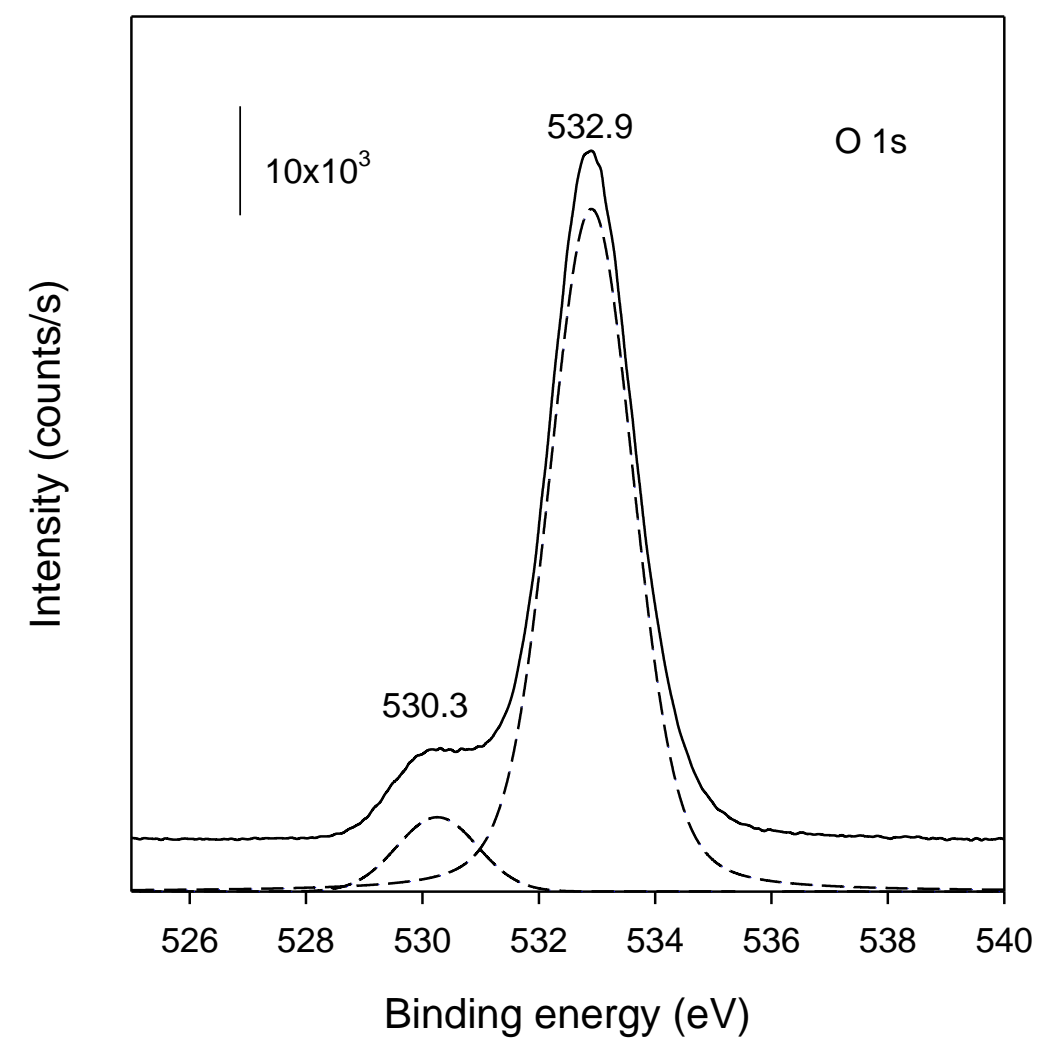

Fig. 6. Adams et al. 


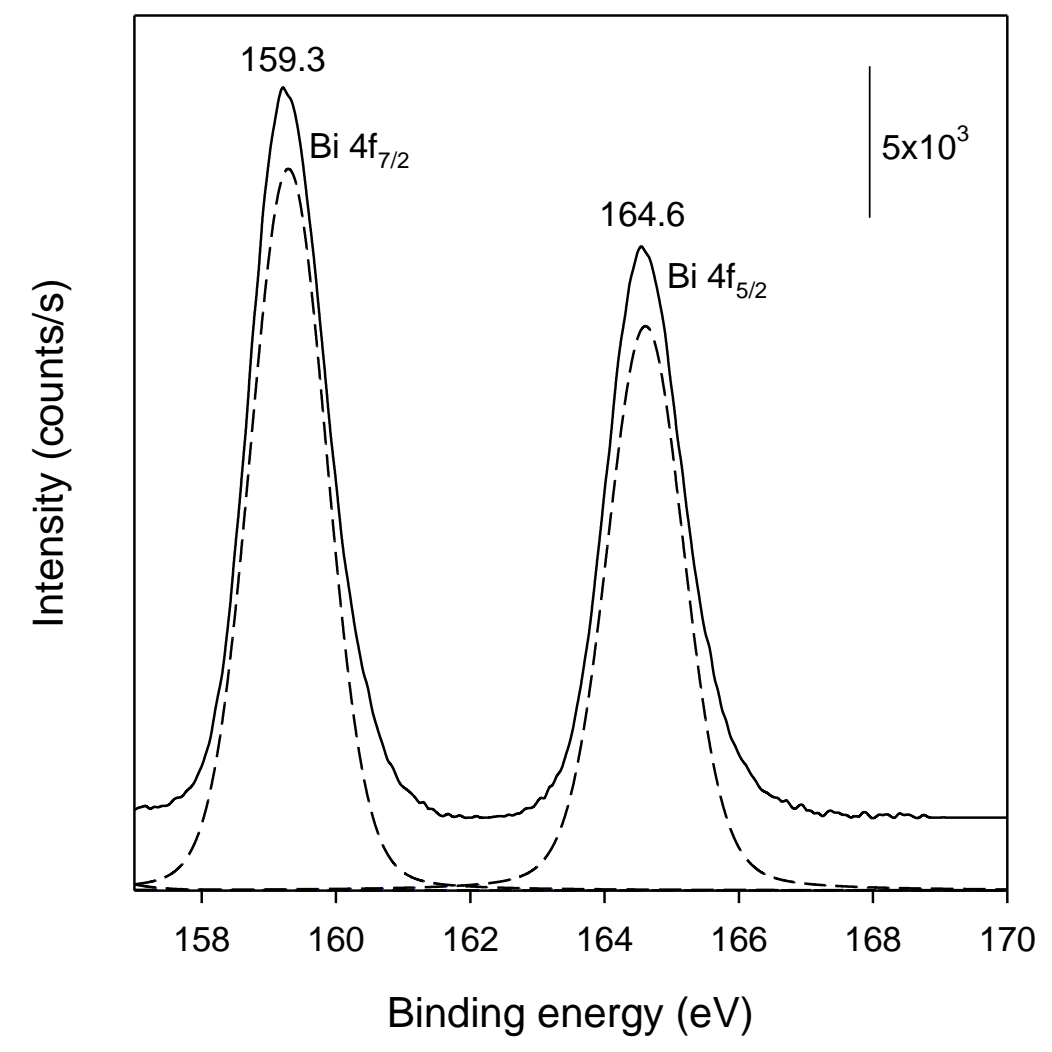

Fig. 7. Adams et al. 


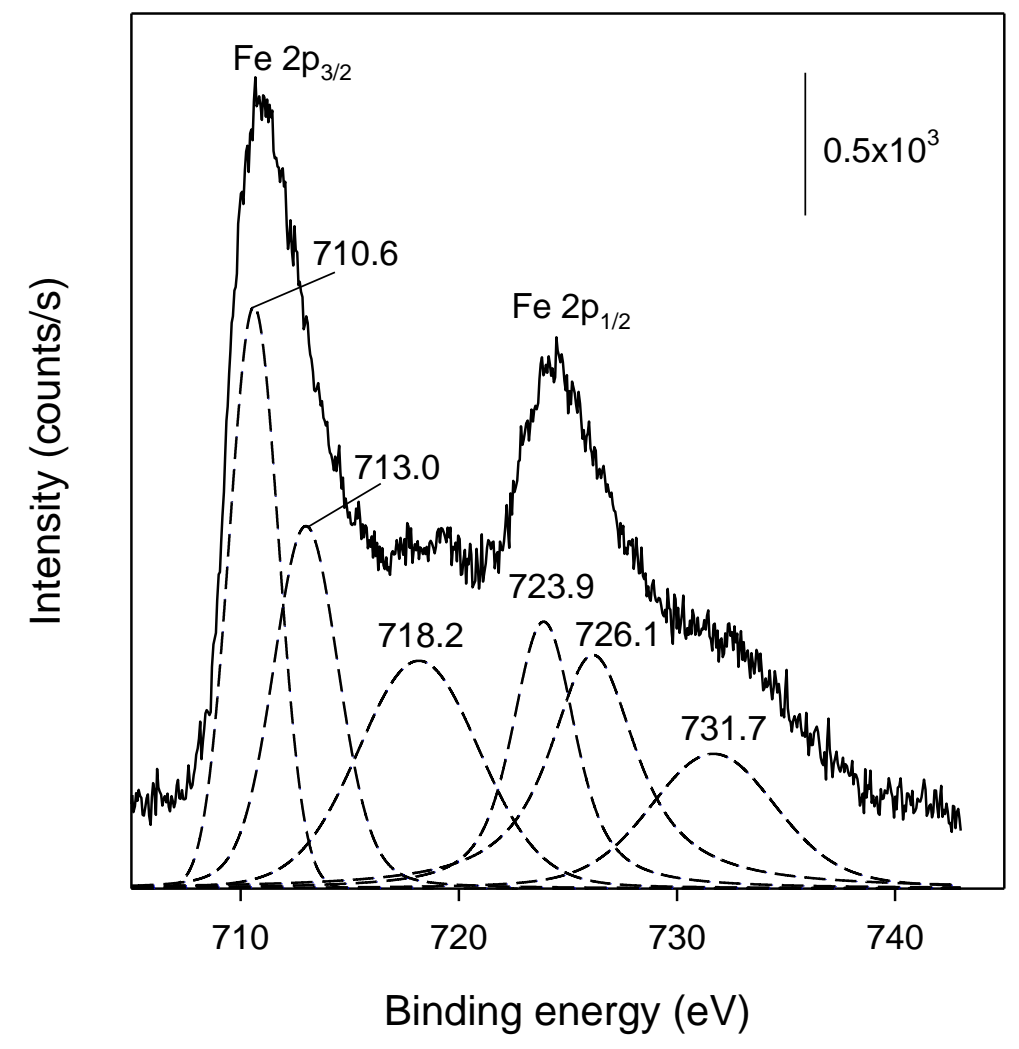

Fig. 8. Adams et al. 


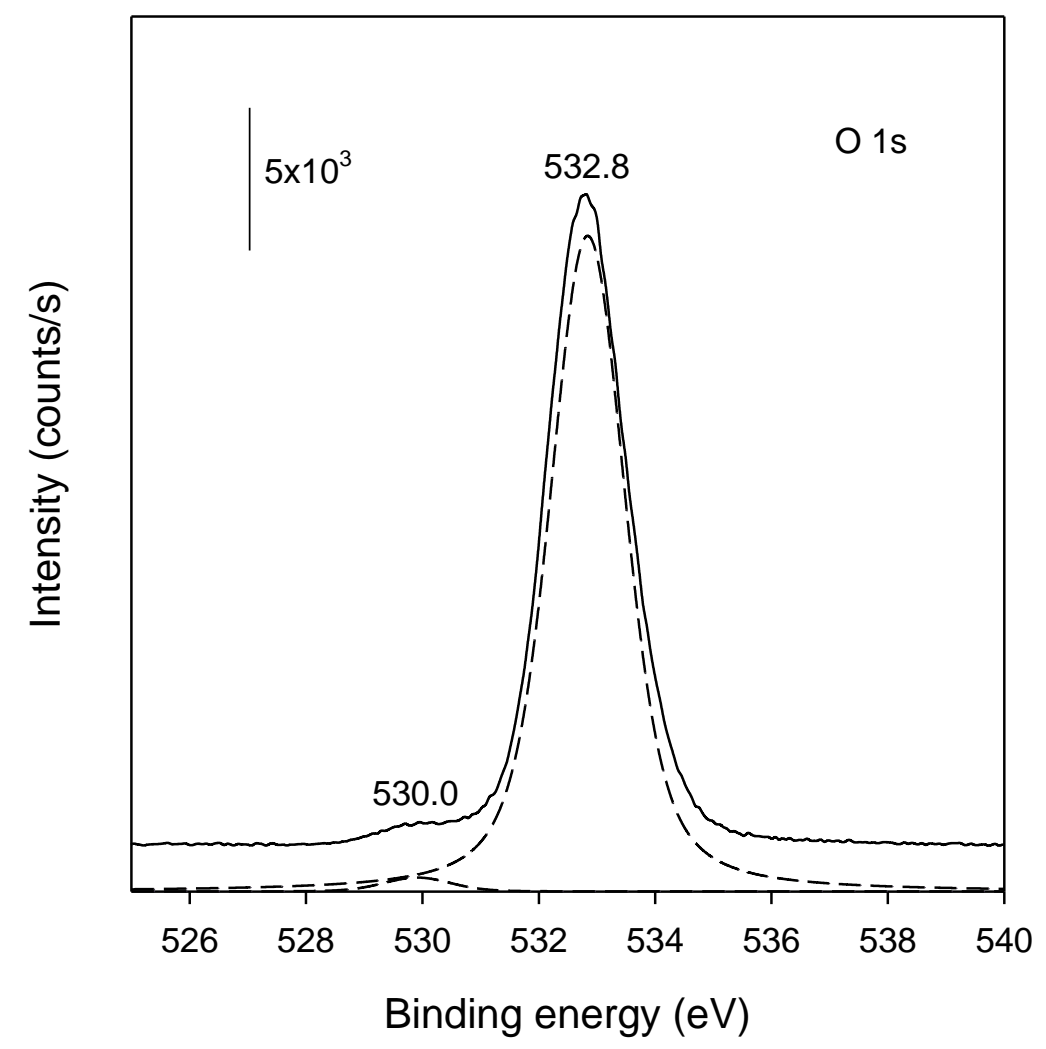

Fig. 9. Adams et al. 


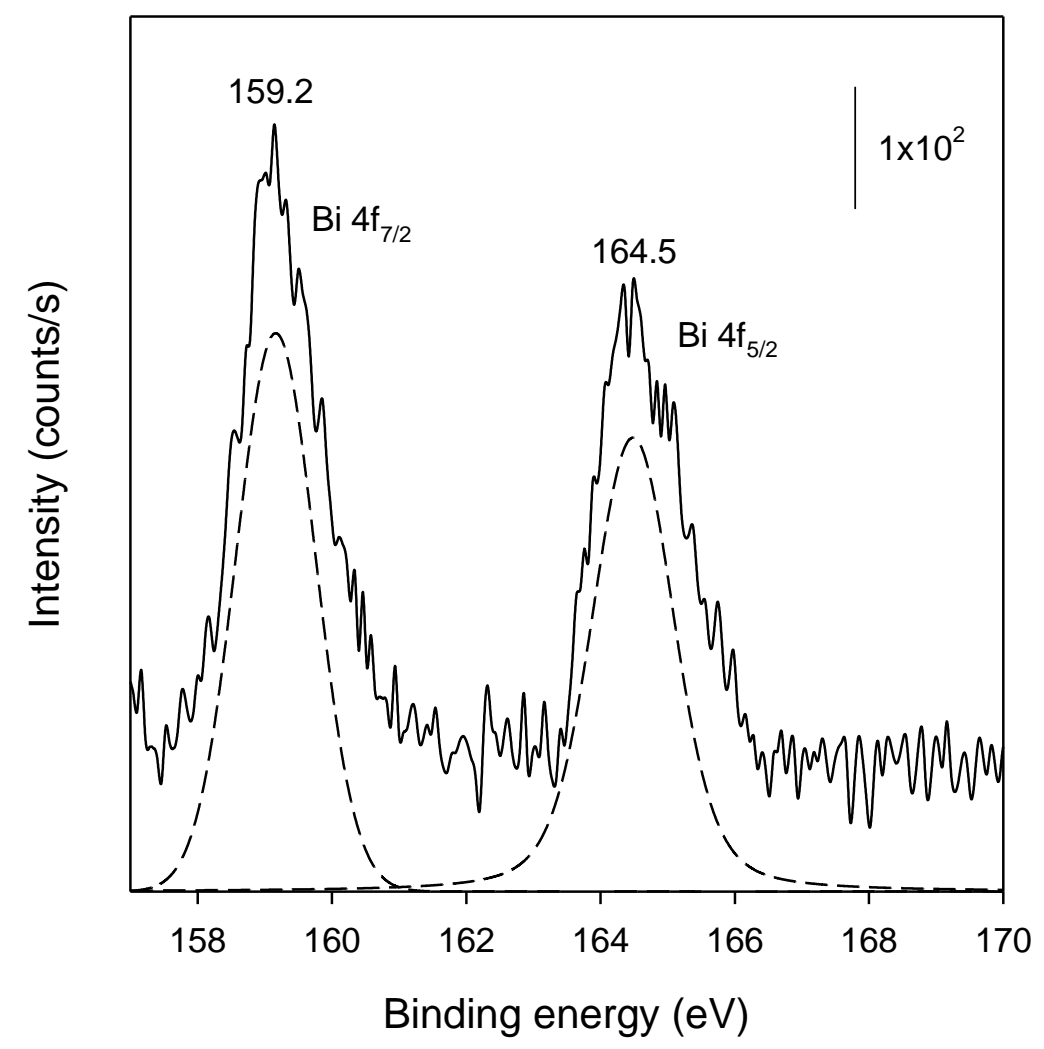

Fig. 10. Adams et al. 


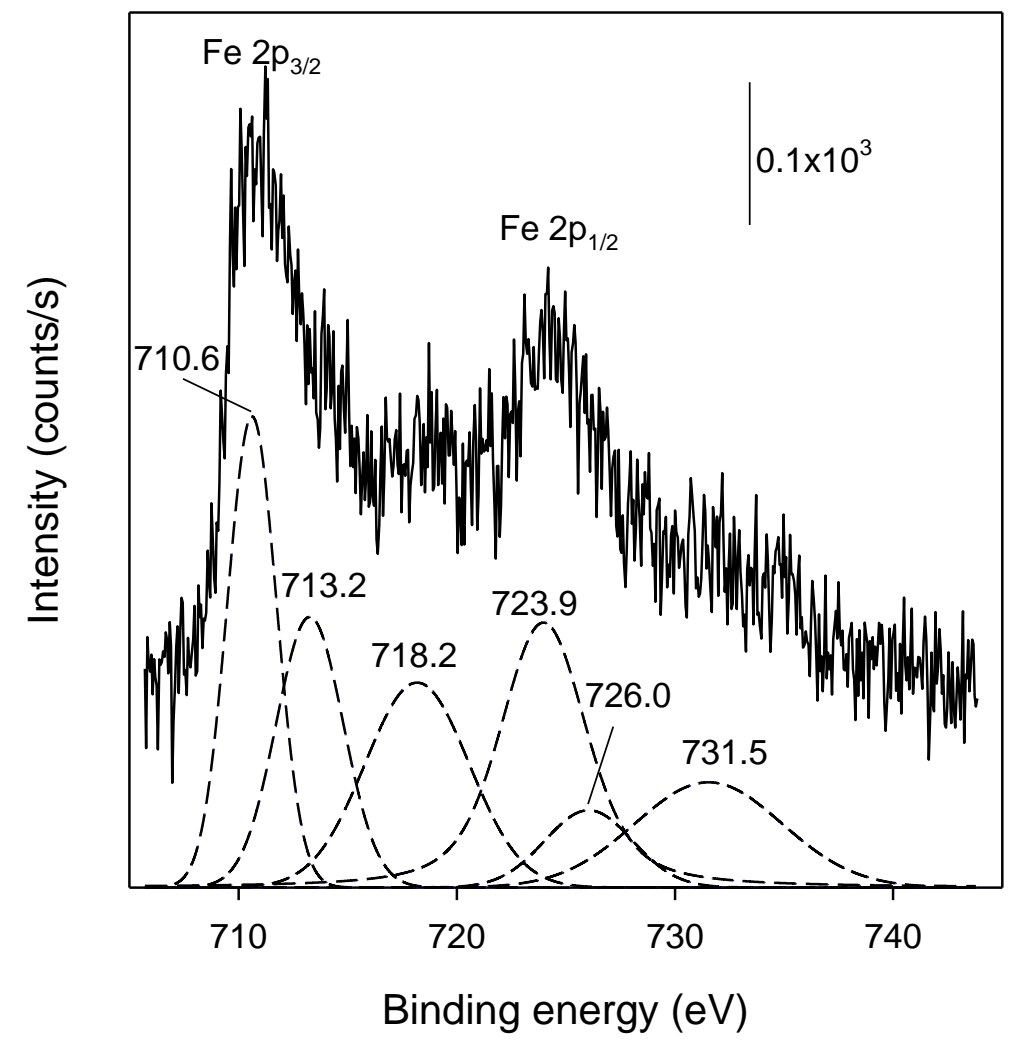

Fig. 11. Adams et al. 